\title{
Corynebacterium hansenii sp. nov., an $\alpha$-glucosidase-negative bacterium related to Corynebacterium xerosis
}

Correspondence

François N. R. Renaud francois.renaud@sante. univ-lyon $1 . \mathrm{fr}$

\author{
François N. R. Renaud, ${ }^{1,2}$ Alain Le Coustumier, ${ }^{3}$ Nathalie Wilhem, ${ }^{3}$ \\ Dominique Aubel, ${ }^{2}$ Philippe Riegel, ${ }^{4}$ Claude Bollet ${ }^{5} \dagger$ and Jean Freney ${ }^{1}$ \\ 'Université de Lyon, Nosoco.tech, ISPB, EA 3090, Université Claude Bernard Lyon 1, \\ Laboratoire de Microbiologie, 8 av. Rockefeller, 69373 Lyon cedex 08, France \\ 2Université de Lyon, IUT A, Université Claude Bernard Lyon 1, Dpt Génie Biologique, \\ 43 bd du 11 novembre 1918, 69622 Villeurbanne cedex, France \\ ${ }^{3}$ Centre hospitalier, 335 rue Président Wilson 46000 Cahors, France \\ ${ }^{4}$ Faculté de Médecine, Université Louis Pasteur, 3 rue Koeberlé, 67000 Strasbourg, France \\ ${ }^{5}$ AP-HM La Timone, 264 rue St Pierre, 13005 Marseille, France
}

\begin{abstract}
A novel strain, $\mathrm{C}-138^{\top}$, belonging to the genus Corynebacterium was isolated from a severe thigh liposarcoma infection and its differentiation from Corynebacterium xerosis and Corynebacterium freneyi is described. Analysis of $16 \mathrm{~S}$ rRNA gene sequences, $r p o B$ sequences and the PCR profile of the 16S-23S spacer regions was not conclusive enough to differentiate strain C-138 ${ }^{\top}$ from C. xerosis and C. freneyi. However, according to DNA-DNA hybridization data strain $\mathrm{C}-138^{\top}$ constitutes a member of a distinct novel species. It can be differentiated from strains of C. xerosis and C. freneyi by colony morphology, the absence of $\alpha$-glucosidase and some biochemical characteristics such as glucose fermentation at $42{ }^{\circ} \mathrm{C}$ and carbon assimilation substrates. The name Corynebacterium hansenii sp. nov. is proposed for this novel species; the type strain is $\mathrm{C}-138^{\top}\left(=\operatorname{CIP} 108444^{\top}=\right.$ CCUG $\left.53252^{\top}\right)$.
\end{abstract}

Corynebacterium xerosis is rarely encountered in clinical samples (Riegel et al., 1996; Funke et al., 1996, 1997b; Wauters et al., 1998). Consequently, the taxon C. xerosis has been excluded from the API (RAPID) coryne database 2.0 (Funke et al., 1997a). In a recent publication (Vela et al., 2006), eight isolates of $C$. xerosis were identified from animal clinical specimens. The situation became more confused with the description of Corynebacterium freneyi by Renaud et al. (2001) as, based on phylogenetic analyses, this species was considered to be closely related to C. xerosis and Corynebacterium amycolatum. Among the biochemical characteristics that differentiate these three species, $\alpha$-glucosidase is known to be positive for C. xerosis ATCC $373^{\mathrm{T}}$ and the reference strain ATCC 7711 (but not strain K132, isolated by Wauters et al., 1998), negative for C. amycolatum, with some exceptions, and positive for C. freneyi (Renaud et al., 2001; Auzias et al., 2003). In this report, a novel species isolated from a human source that is $\alpha$-glucosidase-negative is described.

tDied in 2004.

Abbreviation: ITS, intergenic spacer.

The GenBank/EMBL/DDBJ accession number of the partial 16S rRNA gene sequence of strain $\mathrm{C}-138^{\top}$ is AY684044.
A 77-year-old patient with liposarcoma evolving over a 3 year period was recruited. Surgery was carried out to clean the swelling. The collected pus was cultured aerobically on sheep blood agar in an atmosphere with $10 \% \mathrm{CO}_{2}$. Strain $\mathrm{C}-138^{\mathrm{T}}$ was isolated in mixed culture with a few colonies of a methicillin-susceptible Staphylococcus aureus and some colonies of Corynebacterium pseudodiphtheriticum. Antibiotic susceptibility was determined using Mueller-Hinton medium supplemented with $5 \%(\mathrm{v} / \mathrm{v})$ sheep blood. Biochemical characteristics were determined using the API Coryne strip (bioMérieux). Other identification tests (glucose fermentation at $42{ }^{\circ} \mathrm{C}$ and growth at $20^{\circ} \mathrm{C}$ ) were performed according to Wauters et al. (1998). Carbon substrate assimilation tests were determined with the API $50 \mathrm{CH}$ system (bioMérieux) (Renaud et al., 1998). Using the protocol described previously by Auzias et al. (2003), the partial sequence (952 bp) of the 16S rRNA gene was aligned and compared with all eubacterial $16 \mathrm{~S}$ rRNA gene sequences available in the GenBank and EMBL databases. The partial $r p o B$ gene sequence was amplified with primers $\mathrm{C} 2700 \mathrm{~F}$ and C3130R according to Khamis et al. $(2004,2005)$, except that the hybridization temperature was $51^{\circ} \mathrm{C}$ instead of $57^{\circ} \mathrm{C}$.

Multiple-sequence alignments and similarities (\%) of the $r p o B$ and $16 \mathrm{~S}$ rRNA genes between the various species were 


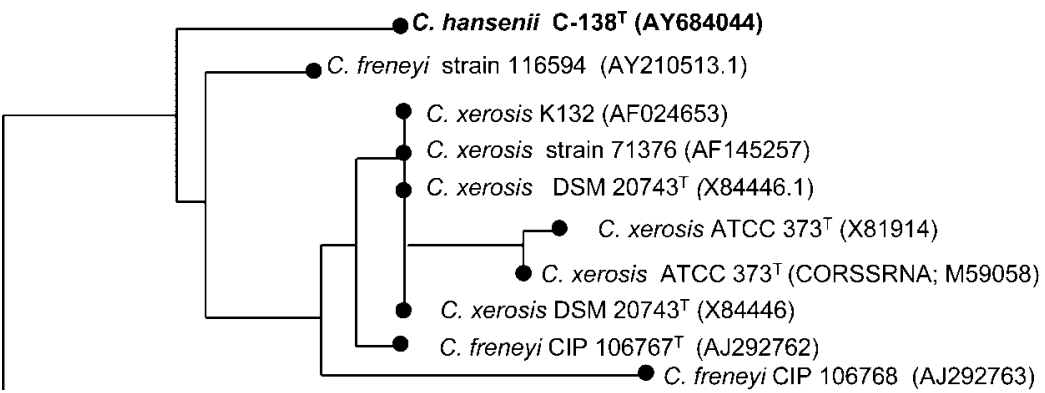

Fig. 1. Dendrogram obtained by analysis of 16S rRNA gene sequences (tree method, fast minimum evolution). GenBank numbers are given in parentheses.

obtained with the CLUSTAL W program available from the EMBL-EBI web server (http://www.ebi.ac.uk/clustalw/). PCR analysis of the 16S-23S intergenic spacer region (ITSPCR) was performed according to the method of Aubel et al. (1997). CfoI was used to digest the amplified products. $C$. xerosis ATCC $373^{\mathrm{T}}$, C. amycolatum CIP $103452^{\mathrm{T}}$ and $C$. freneyi CIP $106767^{\mathrm{T}}$ were also tested for profile comparison purposes. DNA was extracted and purified as described previously (Riegel et al., 1994). Hybridization between labelled DNA of isolate C- $138^{\mathrm{T}}$ and the fragmented DNA preparations of C. freneyi CIP $106767^{\mathrm{T}}$, C. xerosis ATCC $373^{\mathrm{T}}$ and C. amycolatum CIP $103452^{\mathrm{T}}$ was carried out at $60^{\circ} \mathrm{C}$ for $16 \mathrm{~h}$ in $0.42 \mathrm{M} \mathrm{NaCl}$ using the $\mathrm{S} 1$ nuclease-trichloroacetic acid method (Riegel et al., 1994).

Gram staining of strain $\mathrm{C}-138^{\mathrm{T}}$ revealed that it was a Grampositive, non-spore-forming coryneform bacterium. After $48 \mathrm{~h}$ incubation, colonies were yellow-pigmented, very small, dry and rough. The API Coryne code for strain C$138^{\mathrm{T}}$ was 2000325 . Strain C-138 ${ }^{\mathrm{T}}$ was positive for pyrazinamidase, catalase and acid production from glucose, ribose, maltose and sucrose. Fermentation of sugars proceeded slowly during incubation $(48 \mathrm{~h})$. Biochemical differentiation of $C$. xerosis, C. amycolatum and C. freneyi was very difficult. Among the biochemical characteristics that differentiate these three species, $\alpha$-glucosidase is known to be

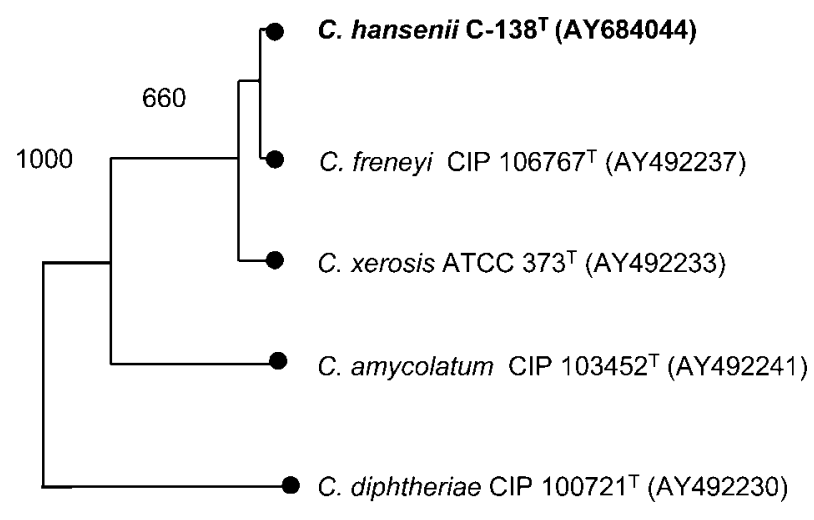

Fig. 2. Dendrogram obtained by analysis of partial $r p o B$ gene sequences (tree method, neighbour-joining). GenBank numbers are given in parentheses. The support of each branch, as determined from 1000 bootstrap samples, is indicated by the value at each node. C. diphtheriae is the outgroup strain. positive for C. xerosis (except for strain K132) and C. freneyi and negative for $C$. amycolatum, with some exceptions, and the present strain $\left(\mathrm{C}-138^{\mathrm{T}}\right)$. Strain $\mathrm{C}-138^{\mathrm{T}}$ was able to grow at $20^{\circ} \mathrm{C}$, but did not ferment glucose at $42{ }^{\circ} \mathrm{C}$. Assimilation tests (API 50CH) were positive for D-ribose, D-galactose, D-glucose, D-fructose and D-mannose and negative for all other substrates. Strain C- $138^{\mathrm{T}}$ was susceptible to almost all tested antibiotics, including amoxicillin, penicillin, imipenem, gentamicin, kanamycin, erythromycin, pristinamycin, rifampicin, vancomycin and teicoplanin. It was resistant to fosfomycin, pefloxacin and tetracycline. 16S rRNA gene sequence analysis showed that strain C-138 ${ }^{\mathrm{T}}$ was closely related to strains of $C$. xerosis and also $C$. freneyi (similarities $>98 \%$ ) and C. amycolatum (similarity >97\%). As the similarity was always higher than $97 \%$, this analysis does not constitute a reliable tool for identification (Stackebrandt \& Goebel, 1994). The dendrogram obtained from sequence

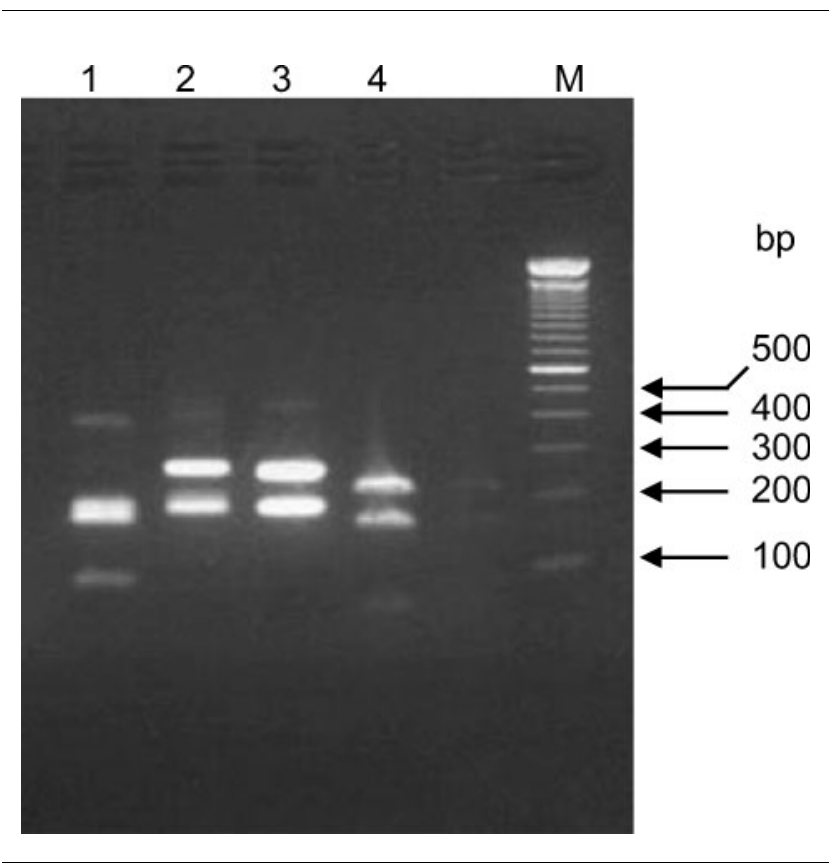

Fig. 3. PCR profiles of the $16 \mathrm{~S}-23 \mathrm{~S}$ spacer regions of Corynebacterium species. Lanes: 1, C. freneyi CIP $106767^{\top}$; 2, C. xerosis ATCC $373^{\top}$; 3 , strain $\mathrm{C}-138^{\top} ; 4$, C. amycolatum CIP $103452^{\top}$; M, DNA ladder (Invitrogen). Profiles 2 and 3 are identical. Profiles 1 and 4 differ from each other and from that of C. xerosis. 
Table 1. Characteristics that differentiate C. hansenii from C. xerosis and C. freneyi

Taxa: 1, C. hansenii sp. nov. C- $138^{\mathrm{T}}$; 2, C. xerosis (Data from Funke et al., 1997b and Wauters et al., 1998); 3, C. freneyi strains CIP $106767^{\mathrm{T}}$ and CIP 106768. +, Positive; -, negative.

\begin{tabular}{|lccc|}
\hline Characteristic & $\mathbf{1}$ & $\mathbf{2}$ & $\mathbf{3}$ \\
\hline Colony description & Yellowish, & Yellowish, & White, small, \\
& small, dry with & small, dry with & dry with \\
& irregular edges & irregular edges & irregular edges \\
Alkaline phosphatase & - & + & + \\
$\alpha$-Glucosidase & - & - & + \\
Fermentation of glucose at $4{ }^{\circ} \mathrm{C}$ & - & + & + \\
Assimilated substrates: & - & + & + \\
D-Maltose & - & + & + \\
D-Turanose & - & & + \\
\hline
\end{tabular}

*One exception.

analysis of various Corynebacterium strains is shown in Fig. 1; strain $\mathrm{C}-138^{\mathrm{T}}$ is not included in the group of $C$. xerosis strains and is not linked to C. freneyi. Partial rpoB sequencing showed that the computed identities between strain C- $138^{\mathrm{T}}$ were $95 \%$ with C. freneyi CIP $106767^{\mathrm{T}}$, $95 \%$ with C. xerosis ATCC $373^{\mathrm{T}}$ and $85 \%$ with C. amycolatum CIP $103452^{\mathrm{T}}$ (Fig. 2). This $95 \%$ similarity value is the cut-off value for differentiating Corynebacterium species (Khamis et al., 2005). In this case, the species could not be differentiated using the $r p o B$ sequencing results. ITS-PCR analysis (Fig. 3) showed that the digestion profiles of strain $\mathrm{C}-138^{\mathrm{T}}$ (lane 2) and C. xerosis (lane 3 ) were identical. The profiles of $C$. freneyi (lane 1) and C. amycolatum (lane 4) differed from each other. In a previous paper (Renaud et al., 2001), the PCR profiles of three C. amycolatum strains, three $C$. freneyi strains and two C. xerosis strains were analysed. Profiles were identical within each species and differed between the species. This method seems to identify strain $\mathrm{C}-138^{\mathrm{T}}$ as a strain of C. xerosis. The DNA-DNA hybridization values between strain $\mathrm{C}-138^{\mathrm{T}}$ and the $C$. xerosis, $C$. freneyi and C. amycolatum type strains were $<40 \%,<47 \%$ and $<15 \%$, respectively. From the data, it is apparent that strain $\mathrm{C}-138^{\mathrm{T}}$ is genomically different from C. xerosis, C. freneyi and $C$. amycolatum and should be assigned as a representative of a novel species.

\section{Description of Corynebacterium hansenii sp. nov.}

Corynebacterium hansenii (han.sen'i.i. N.L. gen. n. hansenii of Hansen, to honour Willy Hansen, a contemporary Belgian microbiologist who died in 2002).

The description given below and in Table 1 is based on the results of studies of one strain. Cells are Gram-positive, non-spore-forming and non-motile. They are typical clubshaped rods. Colonies are yellow-pigmented, very small (0.5-1.0 $\mathrm{mm}$ diameter), dry and rough. Growth is not encouraged in a medium containing lipids. Catalase- and pyrazinamidase-positive. Produces acids from glucose, ribose, maltose and sucrose. Does not reduce nitrates. Does not produce alkaline phosphatase, pyrrolidonyl arylamidase, $\beta$-glucuronidase, $\beta$-galactosidase, $\alpha$-glucosidase or $N$-acetyl- $\beta$-glucosaminidase. Does not hydrolyse aesculin, gelatin or urea. D-Ribose, D-galactose, D-glucose and $\mathrm{D}$-fructose are used as carbon substrates, but D-maltose and D-turanose are not. Glucose is not fermented at $42{ }^{\circ} \mathrm{C}$ and growth occurs at $20^{\circ} \mathrm{C}$. Susceptible to almost all tested antibiotics except for fosfomycin, pefloxacin and tetracycline.

The type strain, C-138 ${ }^{\mathrm{T}}$ ( = CIP $108444^{\mathrm{T}}=$ CCUG $53252^{\mathrm{T}}$ ), was isolated from human liposarcoma pus. The pathogenic role of $C$. hansenii is not known. As the present isolate was found together with C. pseudodiphtheriticum and S. aureus, no conclusions can be drawn about its pathogenicity.

\section{Acknowledgements}

We thank Atieh Khamis for $r p o B$ sequencing and Pr. M. Fussenegger and $\mathrm{H}$. Meugnier for a careful review of this manuscript.

\section{References}

Aubel, D., Renaud, F. N. R. \& Freney, J. (1997). Genomic diversity of several Corynebacterium species identified by amplification of the 16S-23S rRNA gene spacer regions. Int J Syst Bacteriol 47, 767-772.

Auzias, A., Bollet, C., Ayari, R., Drancourt, M. \& Raoult, D. (2003). Corynebacterium freneyi bacteremia. J Clin Microbiol 41, 2777-2778.

Funke, G., Lawson, P. A., Bernard, K. A. \& Collins, M. D. (1996). Most Corynebacterium xerosis strains identified in the routine clinical laboratory correspond to Corynebacterium amycolatum. J Clin Microbiol 34, 1124-1128.

Funke, G., Renaud, F. N. R., Freney, J. \& Riegel, P. (1997a). Multicenter evaluation of the updated and extended API (RAPID) Coryne database 2.0. J Clin Microbiol 35, 3122-3126.

Funke, G., von Graevenitz, A., Clarridge, J. E., III \& Bernard, K. A. (1997b). Clinical microbiology of coryneform bacteria. Clin Microbiol Rev 10, 125-159. 
Khamis, A., Raoult, D. \& La Scola, B. (2004). $r p o B$ gene sequencing for identification of Corynebacterium species. J Clin Microbiol 42, 3925-3931.

Khamis, A., Raoult, D. \& La Scola, B. (2005). Comparison between $r p o B$ and $16 \mathrm{~S}$ rRNA gene sequencing for molecular identification of 168 clinical isolates of Corynebacterium. J Clin Microbiol 43, 1934-1936.

Renaud, F. N. R., Dutaur, M., Daoud, S., Aubel, D., Riegel, P., Monget, D. \& Freney, J. (1998). Differentiation of Corynebacterium amycolatum, C. minutissimum, and C. striatum by carbon substrate assimilation tests. J Clin Microbiol 36, 3698-3702.

Renaud, F. N. R., Aubel, D., Riegel, P., Meugnier, H. \& Bollet, C. (2001). Corynebacterium freneyi sp. nov., $\alpha$-glucosidase-positive strains related to Corynebacterium xerosis. Int J Syst Evol Microbiol 51, 1723-1728.

Riegel, P., de Briel, D., Prevost, G., Jehl, F. \& Monteil, H. (1994). Genomic diversity among Corynebacterium jeikeium strains and comparison with biochemical characteristics and antimicrobial susceptibilities. J Clin Microbiol 32, 1860-1865.

Riegel, P., Ruimy, R., Christen, R. \& Monteil, H. (1996). Species identities and antimicrobial susceptibilities of corynebacteria isolated from various clinical sources. Eur J Clin Microbiol Infect Dis 15, 657-662.

Stackebrandt, E. \& Goebel, B. M. (1994). Taxonomic note: a place for DNA-DNA reassociation and 16S rRNA sequence analysis in the present species definition in bacteriology. Int J Syst Bacteriol 44, 846-849.

Vela, A. I., Gracia, E., Fernandez, A., Dominguez, I. \& FernandezGarayzabal, J. F. (2006). Isolation of Corynebacterium xerosis from animal clinical specimens. J Clin Microbiol 44, 2242-2243.

Wauters, G., Van Bosterhaut, B., Janssens, M. \& Verhaegen, J. (1998). Identification of Corynebacterium amycolatum and other nonlipophilic fermentative corynebacteria of human origin. J Clin Microbiol 36, 1430-1432. 